\title{
"Rise up and walk": Tracing the trajectory of the Carnegie discourse and plotting a way forward
}

NGTT DEEL 55, NR 3 \& 4, 2014

\section{Bowers-Du Toit, Nadine}

Stellenbosch University

\begin{abstract}
This article will provide a comparative analysis of the findings of the first Carnegie Commission on the Poor White Problem, 1932, and the second Carnegie second Carnegie Inquiry into Poverty and Development in Southern Africa, 1982, with regards to the role of the church as an agent of change. It also seeks to navigate the tension inherent in the "double legacy" of the church's historical engagement with issues of poverty and inequality in order to reflect on its current praxis. The article, therefore, highlights both the challenges and opportunities for the church's role as we celebrate 20 years of democracy.
\end{abstract}

\section{KEYWORDS}

Theology and development, Poverty, Inequality, Carnegie, Church, Civil society, Poor white problem, Apartheid

\section{TREFWOORDE}

Teologie en ontwikkeling, Armoede, Ongelykheid, Carnegie, Kerk, Burgerlike samelewing, Armblankevraagstuk, Apartheid

\section{CONTACT DETAIL}

Dr Nadine Bowers-du Toit

Faculty of Theology

Private Bag X1, Matieland, South Africa, 7602

nbowers@sun.ac.za 


\section{INTRODUCTION}

Dr DF Malan challenged the church in 1923 with regard to the condition of the poor white: "If the church wishes to say to the paralysed poor white: 'your sins are forgiven', it must also be prepared to tell him: 'Rise up and walk"' (Boesak, 1984:8). It was this same challenge that Dr Allan Boesak cleverly used as a foil in order to challenge the churches at the time of Carnegie 2 in order to call upon the church to again reflect on its role during the height of the struggle. The challenge to "rise up and walk" is a call from two different vantage points in South Africa's history for the church's on-going and active participation as agents of civil society in the struggle against poverty and inequality. This article traces the trajectory of the church's participation and discourse at key points in South African history with regards to poverty and inequality. The role of the church in each inquiry will be dealt with separately to provide a clear comparative analysis of the first two Carnegie Inquiries (both in terms of their origins and the role played by the church), followed by reflections on the inquiries in light of the church's current role and challenges. Finally, the role and contribution of the church within our current context will be explored. The latter is particularly significant in light of the conference "Towards Carnegie 3: Strategies to overcome poverty and inequality", held in 2012, which gave no clear recognition to the role of the church or religion as a whole. ${ }^{1}$

\section{BRIEF OVERVIEW OF THE ORIGINS OF CARNEGIE 1 \& 2}

The visit of the president of the Carnegie Corporation of New York to the Union of South Africa in 1927 led to a request initiated by the Dutch Reformed Church ${ }^{2}$

1 This article was originally presented as a paper at the conference (held $3-7^{\text {th }}$ September 2012 at UCT) and was originally entitled: 'The Church as an Agent of Change: reflections on the role of the Church in Carnegie 1, 2 and now 3?'. The conference, funded once again by the Carnegie Corporation (and supported by the NDP), sought to bring "together academics, government officials and members of civil society organisations to share ideas and models for effective action in keeping with the goals spelt out in the National Development Plan, notably the elimination of poverty and the significant reduction of the current levels of inequality". (http://www.carnegie3.org.zal about). Although a workshop track was created to accommodate the 5 papers presented from a religious perspective, religion did not feature in the mainstream thinking of the conference. This may also be the case, because of the fact that the conference was largely driven by the goals of the NDP. Furthermore, there appears to be no further progress with regards to a full Carnegie inquiry as with Carnegie I and II, which is why there is no comparative analysis to be made with Carnegie 3.

2 The Dutch Reformed Church of South Africa is also commonly known by its Afrikaans name Die Nederduits Gereformeerde Kerk (NG Kerk) and is referred to as such in the 
to investigate the plight of the poor white largely Afrikaans-speaking sector of the population (Macquarrie, 1933:26). The church and the rulers of the country at that time were deeply concerned about the growing poor white population who dwelt or originated in rural areas and had made their living from farming. The majority of those studied were Afrikaans speaking and what the study termed as "mainly from a Dutch-French-German heritage". ${ }^{3}$ Reasons given for focusing on this particular group of the population were, according to the report, based on what they regarded as a progressive economic and social decline during the forty years preceding the inquiry. The economic deterioration of this sector of the population troubled the government of the day. ${ }^{4}$

Although the "first commission did note the problems of black poverty as not being any less acute than those of poor whites and would require study on their own", blacks were excluded from the inquiry (Wilson \& Ramphele, 1989:x). Blacks and coloureds were viewed as an economic hindrance to the economic progression of the white population, and the population growth of the black and coloured sectors of the population were viewed as alarming. This, combined with their acquisition of skills that were on par with those of many poor whites, was seen as both economically threatening and psychologically demoralising for the poor white (Albertyn \& Rothman, 1932:xix). Job reservation, which the inquiry proposed for a set, temporary period, was therefore proposed as the answer to this quandary (Albertyn \& Rothman, 1932: xx; cf. Maquarrie, 1933:28). ${ }^{5}$ The success of this first inquiry is evident today. The poor white problem receded as many of these findings were incorporated into National Party policies, which formed, in part, the sociological and ideological motivation for apartheid and its subsequent policies which included recommendations such as job reservation (Albertyn \& Rothman, 1932: xx; cf. Wilson \& Ramphele, 1989: x).

inquiry. During the apartheid era, this denomination helped to propagate the concept of separate development on which the policy of apartheid was based.

3 In the original Afrikaans, it reads "hoofsaaklik van Hollands-Frans-Duitse afstamming".

4 Wilson and Ramphele (1989:viii) explain it in the preface of their book as an introduction to the second inquiry: "Large numbers of whites, uprooted from the land during the previous generation by war, drought, pestilence, population growth, and the capitalization of agriculture, were pouring into the cities to live, ill equipped for modern industrial society, in dire poverty."

5 It is important to note that the expansion of gold mining in the 1930s and industrial developments of the Second World War also contributed to the proposal forfjob reservation for poor whites (Wilson \& Ramphele, 1989:x). 
By the time of Carnegie 2 more than 50 years later, poverty had become a "profoundly political issue" (Wilson \& Ramphele 1989:4). Gross inequality was the direct result of the racial policies that flowed, in part, from recommendations such as job reservation, resulting in the racially correlated distribution of income. Carnegie 2 therefore identified poverty as being largely the "consequence of deliberate policy": "racist policies that are an assault on people's humanity" (Wilson \& Ramphele, 1989:4). ${ }^{6}$ At the Conference on the Second Carnegie Inquiry into Poverty and Development, the president of the Carnegie Corporation labelled the first inquiry "a partial success" due to this omission. He went on to comment that it "failed to recognize fully the humanity of black Africans", and that "this was the direct result of the thinking of the day" when "so many dark skinned people around the world, were dimly viewed as peripheral to human society, almost as non-persons" (Hamburg, 1984:10). The suggestion of a separate inquiry into black poverty had, however, been made by several researchers at the time of the first inquiry. In the 1930s, one of the Carnegie commissioners proposed such an inquiry and in the 1940s, the historian CW Kiewiet added his voice to this proposal. The South African Outlook of March $1933^{7}$ (in Hamburg, 1984:12) had also observed:

We shall have to learn to view the Non-European population as an integral part of the socio-economic system of South Africa and to let them fit into the whole as effectively as possible, both as producers and consumers.

Nevertheless, the omission of this sector of the population was rectified only with the process of the initiation of The Second Carnegie Inquiry into Poverty and Development in 1980.

\section{3. "RISE UP AND WALK": THE ROLE OF THE CHURCH IN CARNEGIE $1 \& 2$}

The following section traces the role played by the church in both Carnegie 1 and 2 and also highlights the recommendations and challenges identified by these inquiries at the time.

6 See also the entire chapter in Wilson \& Ramphele (1989) on "Apartheid's Assault on the Poor".

7 The South African Outlook is a journal that dealt with ecumenical and racial affairs since 1870 . 


\subsection{Carnegie 1}

The first Carnegie inquiry acknowledges that the social consciousness of the church awoke much sooner "than that of the state or society at large" (The Poor White and Society, 1933:151). The role of the church in initiating and even assisting Carnegie 1 was significant and it was acknowledged by the researchers who included it in the study of the upliftment of the poor white. ${ }^{8}$ This commission consisted largely of clergy from the Dutch Reformed Church and operated in much the same way as the other commissions.

The methodology used in Carnegie 1 appeared to combine the commissioners' reports with church statistics and a brief history of ecclesiastical endeavours (Albertyn \& Rothman, 1932:4, 49). The role of the Dutch Reformed Church (DRC) in the life of the Afrikaner nation is a significant one and has been traced by the 1932 inquiry in its "Kort geskiedenis van die kerklike armsorg in die verlede" ("A Short History of Church Charity in the Past"). Their many welfare institutions ministered to the orphaned, sick, widowed, handicapped and aged, and continue to exist today ${ }^{9}$ (Albertyn \& Rothman, 1932:50-51). In addition to institutional care, the report also outlined what the Dutch Reformed Church referred to as "kerklike armsorg", namely caring for the poor within the context of their local churches and area groupings in the form of commissions, various associations and a broad federal commission on national level (Albertyn \& Rothman, 1932:52, 53). Deacons and elders were also part of the local church's diaconate work in "the allocation of a small monthly grant to a few chronic sick, widows and others in distress who are not old enough to receive the old-age pension" (Albertyn \& Rothman, 1932:60).

In this way, the Dutch sister churches' involvement in poverty upliftment was viewed as having great value by the first inquiry. In fact, the church was viewed as a powerful preventative measure against despondency and apathy during disasters, as well as against selfishness and extravagance in times of prosperity (Rothman \&

8 It should be noted that "church" refers here to the Afrikaans family of Reformed churches, namely the Dutch Reformed Church, Hervormde Church and Gereformeerde Church - these churches ministered mainly amongst the studied group (The Poor White and Society, 1933:151).

9 It should be noted that while many of these institutions are still in existence, many of those in the Western, Eastern and Northern Cape are now under the care of Badisa - a united diaconical ministry of the URCSA (Uniting Reformed Church - former NG Sendingkerk) and the NGKSA. While Badisa remains what their website terms "a church based social services organisation", it is registered as a non-profit organisation and provides both residential and community services (http://www.badisa.org.za/index. php/en/who-we-are). 
Albertyn, 1932:51). The findings indicated that, where the church continued to play an important role in the poor white family, the family was protected from descending into what the inquiry referred to as a demoralising state of "poor whitism" ${ }^{10}$ It furthermore showed that the church played a key role in maintaining the moral structure of the Afrikaner nation and that the decline of morality was a direct byproduct of the breakdown of the church's authority and traditions (The Poor White and Society, 1933:151). While social work was considered relatively new at that time, the church was acknowledged as having "woken up" to social needs much sooner than the state, as illustrated by the establishment of the many social institutions that the church had initiated (Albertyn \& Rothman 1932:57). ${ }^{11}$

Nevertheless, the church, largely owing to its conservatism, was regarded as not fully alive to the situation created by the vast social changes of later years, and was "found wanting both with respect to its methods and to the number and equipment of its workers" (Rothman \& Albertyn, 1932:56; The Poor White and Society, 1933:151). The first inquiry's evaluation of the church's policy looked critically at the need for "greater enthusiasm" on the part of the church with regard to social work, in comparison to the state and broader civil society. Its methods were also identified as being inadequate - even at this time the institutional approach was regarded as inadequate in addressing the "complicated problems of poverty, pauperism and crime" (Albertyn \& Rothman, 1932:58). The church was encouraged to "take steps for the more efficient training of its agents in charitable work". Theological seminaries were criticised for giving "almost no training in practical sociology", despite large congregations. The use of qualified social workers was also encouraged and the teaching of the church was to be more "pertinent and practical" (The Poor White and Society, 1933:151).

Nevertheless, the evaluation of the church's involvement in the social diaconate included critique of both its methodology and the theological assumptions underlying its response to poverty. The direct involvement of the church offices of deacon and elder respectively, according to the commission's evaluation of the New Testament's characterisation, appeared to be inadequate. The comparison was made between the early church's definition and its role today, and it was found that "a misconception of the deacon's office and the neglect of his true work" in terms of the scriptural definition were partly to blame (Albertyn \& Rothman, 1932:60). The next reason put forward by the inquiry was that it was incorrect to place the responsibility

10 In Afrikaans this is referred to as "armblankedom".

11 It is a widely acknowledged fact that much societal transformation, from the church's founding up until today has been initiated be the church (Cf. Pierson, 1993:8). 
largely in the hands of the state. The misconception that the responsibility should lie mainly in the state's hands, the commission believed, led to a one-sided charity approach that often led to dependency. Many churches were more prone to give a "small sum towards charity" and, considering their duty fulfilled, left "the rest to the local authorities or the government" (Albertyn \& Rothman 1932:60, 61). This form of charity without personal care was considered to have led to an increase in "dependency and pauperism". Perhaps one of the most prominent reasons put forward at the time for the church's insufficient social care (one which many evangelical churches are still accused of today) is that:

The Church has in the past aimed too exclusively at preparing its people for the hereafter, and has therefore bestowed too little attention on the amelioration of present conditions. It taught the poor to resign themselves to want and poverty, in the hope of better conditions hereafter, instead of actively assisting them to a better and higher life here (Albertyn \& Rothman 1932:58).

This spiritualisation of the Gospel neither proclaimed nor acted on the whole calling of the church and was therefore quite straightforwardly addressed by the first inquiry. The dualism, which underlay this separation of the sacred and secular, was pointed out as being incongruent with the message and ministry of Christ. Social action (the social) and the 'religious calling' (the spiritual) of the church were stated as not being antagonistic, but complementary. One of the questions that arose out of this critical analysis was the following: "Is it the duty of the church to interest itself more closely in the social conditions under which its people are living? If so, will its spiritual calling necessarily suffer as a result?"(Albertyn \& Rothman, 1932:58). The answer appeared to be that, if the church refused to take up the gauntlet, its work would be taken out of its hands and it would lose "influence and authority with regards to the great social questions of the country" (Albertyn \& Rothman, 1932:58). Needless to say, the role of the church in the poor white problem was significant and not without its bias as the church was deeply involved in both sponsorship and research.

\subsection{Carnegie 2}

The second inquiry took place largely against the background of the success of the first, and was no different with regard to the involvement of the church. Boesak $(1984: 6,7)$, when researching the church's role in the first inquiry, had gone so far as to use Carnegie 1 as a foil in order to highlight the Dutch Reformed Church's balanced view of social upliftment as part of the missiological calling of the church in contrast to the apathy of many churches at the time of the second inquiry. 
One cannot help but notice the important role played by the white Dutch Reformed Church in the Carnegie Commission on Poverty. It was very much part of the initiative, it helped to define a new relationship with the state in coping with the problem of poverty, and in the process it defined a new role for itself as agent for change in society (Boesak, 1984: 6).

Yet, their inability to apply it universally to their black brothers and sisters in much the same plight was challenged. ${ }^{12}$ He attacked the Dutch Reformed Church, which had so significantly improved the lot of its members and volk, ${ }^{13}$ and which now supported a system, Boesak argued, that led to the deprivation of other sectors of the population. It is within the context of liberation and upliftment of those ignored by Carnegie 1 that the church's study took place. However, the challenges posed to the church in terms of meeting its social challenges in Carnegie I are not unlike those that were faced at the time of the second inquiry. ${ }^{14}$

Perhaps because of (or in spite of) Carnegie 1, Carnegie 2 had clearly continued to regard the input of the church as being significant enough to warrant a working group on Church, Poverty and Development, which was initiated in the early stages of the inquiry. Unlike the first inquiry, the working group was intended to be interdenominational and "members were invited from a variety of backgrounds denominational, rural/urban etc." However, those who attended represented a very narrow constituency (Nash, 1984a:2). ${ }^{15}$ The more open and strategically orientated format of the Carnegie 2 workgroup included meetings and workshops on both urban and rural development (the former in Montagu and the latter in Lavender Hill). Meetings were "devoted to information gathering, review and analysis of church situations vis-à-vis poverty and development, identifying resources and exploring possibilities of practical action, especially in community development projects" (Nash, 1984a:3). A field trip was undertaken by two members of the group who

12 Boesak (1984:7) states that "this church persistently denies that apartheid, even though the evidence is abundantly clear, is responsible for the deprivation, misery and poverty in which millions of black people are forced to live ... apartheid is executed according to the principles of love and justice, and is therefore not in conflict with the demands of the Word of God".

13 Cf. Ras, Volk, Nasie en Volkverhoudinge (1975) for the Dutch Reformed Church's theological justification for the support of apartheid.

14 The approach of the workgroup was based largely on the Liberation Theology of Latin America and the WCC/CCPD (Commission on the Churches' Participation in Development) (Nash, 1984a:3).

15 They did not officially represent their respective Churches and there was only official consultation and cooperation with the NGSK Commission on Poverty (Nash, 1984a:2) 
backpacked for a week through poverty-stricken areas in the Eastern Transvaal ${ }^{16}$ in order to interview people and obtain first-hand information. A letter was also addressed to church leaders inviting them to place poverty and development high on their agendas (Nash, 1984a:2-4). The aim of this workgroup was to conscientise churches and to provide resources for addressing the challenges of poverty and development. The South African church at the time was divided along lines of privilege as much as the country was:

In South Africa the governing bodies of the 'multi-racial' denominations tend to be dominated by those who enjoy secular privilege and are predominately white, although most of the members are black, poor and ill educated (Nash, 1984b:38).

They thus tended to reflect the same divisions of wealth as the secular society did. Nash (1984a:16) strongly attacked those churches as offering little resistance or alternative to a racist system beyond lip service. Even the leaders of the African Independent Churches were accused of subscribing to "conspicuous consumption" patterns and living a lifestyle far removed from those of the underprivileged / oppressed black sector they served. Allan Boesak's attack (in Wilson 1989:83) on the Dutch Reformed Church clearly highlighted the fact that sectors of the church in South Africa were still not fully involved in facing the crises of poverty, which he saw as being political, "not metaphysical or God-given, but structural and historically explicable". ${ }^{17}$ In his paper "Rise up and Walk", he conducted a sociological analysis to paint the picture of poverty in South Africa at that time, with particular reference to the role political oppression played in widespread deprivation. ${ }^{18}$

For the powerlessness of the poor is the precondition for the continued dominance of the rich. We must expose the relationship between poverty and wealth. The poor are so poor because the rich are so rich. The process of accumulation of wealth and the law of the market prevailing in many countries including our own, create and sustain wealth for the wealthy and poverty for the poor (Boesak, 1984:2,3).

16 Now known as Mpumalanga Province.

17 One of the key tenants of Liberation Theology is to be committed "to a lifestyle of solidarity with the poor and oppressed and involvement in action with them" (Thomas, 1995:185).

18 Liberation Theology views poverty as a result of oppressive and exploitative practices exercised by the "haves" over the "have nots" and therefore poverty is not merely as a result of "just ignorance, lack of skills or cultural or moral factors" (Bosch, 1991:434). 
The churches were therefore urged to take political action in campaigning for the abolition of pass laws, influx control, and land ownership laws ${ }^{19}$ and therefore the improvement of family life. Churches were called upon to face these issues on an institutional level and use their church structures to "mount large scale campaigns" on a macro level as well as on the micro, in terms of short-term schemes and action on the congregational or parish level (Wilson, 1984b:82.83). Margaret Nash (1984b:38) however does acknowledge the efforts of various clergy, laity and other Christian organisations in bringing a holistic Gospel of good news to the poor, doing so often in the face of controversy and risking the wrath of the state. In this way, the Church, Poverty and Development workgroup sought to highlight that the church in South Africa at that time was part of the problem, but was and could be a significant part of the solution. ${ }^{20}$ The workgroup proposed that churches were a source of strength and initiative in confronting poverty through their Christian identity, loyalty, history and people (Nash, 1984a:18).

The role of the church in combating poverty was therefore often ambiguous. It is interesting to note that one of the key reasons noted for this situation differs very little from that noted 50 years earlier by Carnegie 1. Yet again the church (albeit now not merely the Reformed sister churches as in Carnegie 1) is accused of a dualistic spiritualisation of the Gospel, which is cited by Nash (1984b:38) as "directing hope towards the life hereafter and has the same effects as Valium ... tends to buttress rather than challenge the status quo". ${ }^{21}$ Nash (1984:38) also noted that "heavy emphasis on the individual, who is encouraged to work hard, spend wisely and give generously to the Church" as a value system, has a similar effect on church members. Such approaches ignore the systemic nature of poverty and it therefore appears that the key challenge of workgroup appeared to be that they needed to state clearly that

19 The Native Land Act (1913) and Native Laws Amendment Act (1937) limited black land ownership and settlement to existing tribal 'reserves'. Africans could not own land in urban areas and their movement was limited - they could only reside in an urban area if they were employed and carried a pass (Van Donk, 1994:5, 6).

20 Many churches made submissions to the Truth and Reconciliation Commission with regard to their sanction of apartheid in the past (Cochrane, De Gruchy\& Martin 1999:15-77). Many, however, fought the policies and ideology of apartheid labelling it heresy (cf. De Gruchy, J \& Villa-Vicencio, C1983. Apartheid is Heresy. Cape Town: David Philip).

21 Cf. Albertyn \& Rothman (1932:58) for a similar identification of a dualistic spiritualisation of the gospel during the first Carnegie Inquiry. It should be noted that one of the characteristics of Liberation Theology, operating within South Africa at that time, is its rejection of both an interpretation of faith "in otherworldly categories and excessive individualism" (Bosch, 1991:438) 
poverty "poverty is a moral challenge!" (Boesak, 1984:3) Nash (1984b:38) challenged the church "to be liberated and liberate" in confronting this challenge and set forth the following as markers in this path:

These change seekers ${ }^{22}$ will make headway only as they:

1. Develop solidarity with one another and with their servant-Lord; and

2. 'Walk on two legs'- act both in the secular society and in the organized church communities.

The key question was how best to mobilise and equip the poor who were dominated in their local or denominational contexts by a privileged minority. The answer was that renewal of the church in South Africa was perceived within this liberation paradigm, whereby the church was to be renewed from the bottom up through basic Christian communities (consisting of class betrayers and the poor) committed to the values of the Kingdom and therefore a holistic gospel. ${ }^{23}$

The latter shaped the way that recommendations for action were then made. Far removed from the methodology of Carnegie 1, the workgroup had composed a 'dossier' consisting of case studies of church and community; a draft chapter for use in a manual or resource book; lines of action to combat poverty and promoting community development in local churches; and a paper on the use of regional church structures in community development. ${ }^{24}$ These recommendations, it was hoped, would provide a resource and challenge to the churches in dealing with poverty.

22 It is interesting to note that "these change seekers" are viewed by the author to be a select group who may be from differing socio-economic and ecclesiastical backgrounds, and who could be "class betrayers".

23 See Boff (1986) for a discussion on base communities and their role in liberation in the Latin American context.

24 Five lines of action were identified by the workgroup as ways for the church to address poverty:

1. Relate preaching and teaching to social reality;

2. Fact find and analyse findings of needs and resources;

3. Encourage self help initiatives and "collective self reliance";

4. "Identify and oppose unjust social structures"; and

5. "Search for and promote just social structures" (Nash, 1984a:21). 


\section{REFLECTIONS ON THE INQUIRIES IN LIGHT OF THE CHURCH'S CURRENT ROLE AND CHALLENGES}

It is evident that both inquiries greatly valued the role of the church in addressing issues of poverty and that the government (during the time of Carnegie 1) and civil society (at the time of Carnegie 2) felt it had a vital role to play in this regard. Indeed, Carnegie 2 argued that the church's Christian identity, loyalty, history and people were a source of strength and initiative. Several more recent studies confirm that the church continues to be recognized, particularly in marginalized and poor communities, as an institution to be trusted which indeed points to the fact that churches "could be viewed by policy makers and other strategists as an important channel of opportunity to enter the respective communities and establish contact with the local people" (Swart, 2010:343; cf. Krige, 2008:132; cf. Erasmus, 2012:59, 60). In fact, furthermore, churches, as pointed out by Carnegie I, often provide a "buffer" against the powerlessness and despair engendered by poverty as spirituality is often a key resource for the poor in weathering the many challenges they face. ${ }^{25}$

It is further evident in both Carnegie $1 \& 2$ that the church has a socio-political role to play. While the church's prominent role in driving the first inquiry, may now be tainted with the bias of the first inquiry towards the Afrikaner, it is nevertheless evident that the reformed churches of that era regarded it as part of their role to be engaged in society. Boesak's borrowed challenge in Carnegie II that the church 'rise up and walk', was in no way different as it re-posed this challenge for the church as a whole to engage within a new context of poverty and inequality. More specifically, Boesak was challenging the powers that be (and the church community that often supported them) to recognize that poverty cannot be spoken about without touching on power. The challenge made by Boesak is of course that in the days of Carnegie 2 the church had to mobilise its powerbase - power through numbers, reach and moral authority to engage the government of the day if united. This challenge was indeed taken up by many sectors of the Christian community at the time. Today it is the state that is calling for active citizenry by members of civil society in the form of the National Development Plan (NDP). It is clear from the NDP documents that the approach to change is based on the kind of active citizenry our brief account of the church's engagement with the scourge of poverty and inequality already describes. Although the NDP does not expressly mention religious bodies such as the church, its call to active citizenry is a call to all of civil society (NDP nd:16,27).

The NDP's call to action is echoed by respondents interviewed for a study of the Paarl area a few years ago regarding the church's role with regards to poverty. These

25 Studies on social cohesion certainly point to churches as a generator of this. 
respondents felt that the church, as a civil society role player, could be playing the same role of mobilising people as they did in the past, but now to address the widespread poverty and inequality communities face currently (Erasmus, 2008:53). It is also interesting to note that many volunteers who assist in the kind of active citizenship called for by the NDP today, are motivated by their calling as people of faith (cf. Burger, Louw \& Van Der Watt, 2010:68). Respondents at grassroots had also noted that the church was becoming almost invisible, "afraid to voice their opinions on certain issues and this makes them seem weak to the public" (Erasmus, 2012:252) Certainly the NDP (at least on paper) challenges citizens to engage in "robust public discourse" and hold government to account (NDP nd:27). The challenges posed by the NDP to citizens, calls the church to rise up and walk alongside as a partner called and challenged by a just and loving God. Some have noted that in a post-apartheid South Africa the church appears to be losing its moral standing within the public sphere and is often silent on issues of injustice and poverty (cf. Erasmus, 2012:252; McMaster, 2008:3). Perhaps the latter is only an echo of the fact that often ministers themselves, shy away from the kind of social preaching and teaching advocated for by Carnegie 2, as evidenced by a recent doctoral dissertation in Homiletics (see Burrows 2014). ${ }^{26}$ The church, therefore only appears to be 'walking on one leg', rather than the two proposed by Carnegie II, which was to act both in the church and society.

Poverty in South Africa at the time of Carnegie 2 was of course not only a socioeconomic issue, but also a profoundly political issue. Gross inequality was the direct result of the racial policies that flowed from the recommendations of Carnegie 1, such as job reservation, which resulted in the racially correlated distribution of income that remains our legacy. This legacy is one that demands that we view restorative justice in a new key: that of economic restitution and reparations. This is enormously challenging in a still divided South Africa, where the church often remains divided along racial lines and inequality often mirrors that of society ${ }^{27}$ (cf. Bowers-Du Toit, 2012). The response to poverty, therefore, remains a justice issue not a charity issue. It, therefore, remains the contention of some that just as the church played a key

26 Burrows (2014: 185-186) doctoral work highlights the fact although the laity ascribe significance to preaching in terms of concientisation on socio-political issues, many ministers continue to preach a-political moralistic sermons which make little mention of the real issues faced by congregants.

27 While poverty remains a political issue as the inequality rendered by the Apartheid legacy remains racially skewed, today lines are no longer drawn by race alone. We as the church will have to grapple with issues of class and economic stratification, if we are to meet this challenge in a new key (Burger, Louw \& Van Der Watt, 2010:69). 
role in both institutionalising and opposing apartheid era socio-economic factors, it is also the church that can assist in bridging the socio-economic divide. One of the neglected arenas of addressing issues of socio-economic redress at grassroots level is that of congregational engagement. The biblical call to 'love thy neighbour' demands a "stepping across boundaries of class and/or race" and requires "being with the poor, not merely "for the poor" (Bowers-Du Toit, 2012:260). The latter is an act of justice displayed as love and, should not therefore deteriorate into a charity or even project - based approach, which sees little or no engagement with brothers and sisters on the other side of the socio-economic and racial divide. Bowers-Du Toit \& Nkomo (2014:14) note the following:

The charity and 'ad hoc' approaches employed by congregations in addressing poverty within South Africa, while well meaning, do not acknowledge the structural nature of the system of poverty and inequality engendered by Apartheid. To repair the past demands far more than this, as the case study tentatively plots. It is those 'majority White' congregations, who not only acknowledged the injustice of Apartheid, but have sacrificially reached out in intentional ways to build relationships across the divide as part of their attempt to restore the socio-economic injustices of the past, that have made the most progress.

This, however, remains a complex undertaking (and perhaps an over optimistic vision) as it assumes that congregations, in particular, are prepared to reach out reciprocally in the manner alluded to by the previous quotation. ${ }^{28}$ Nevertheless, although the will to view socio-economic redress as restorative justice must, therefore, be driven at all levels/configurations of the $\operatorname{church}^{29}$ it is at grassroots that the church really struggles to engage issues of socio-economic redress in a manner that does not revert to paternalistic modes of charity.

The aforementioned tendency towards charity or welfare, rather than justice in the form of sustainable interventions, was identified as far back as Carnegie I. The findings of Carnegie I indicted that the Reformed churches had tended to place the responsibility of addressing poverty largely with the state, which the inquiry argued led to a "one sided charity approach which promoted dependency". Today, the church

28 Cf. Swart, I 2012. Are the Rising Expectations Realistic? Local Churches and Social Welfare in South Africa and Paarl, in Swart, I et al (eds), Welfare, Religion and Gender in Post-Aparthied South Africa: a South-North Dialogue. 285-303, Stellenbosch: Sun Press

29 Smit (1996) famously highlights six configurations of church, namely: church as worshipping community; church as congregation, church as denomination, church as individual believers, church as volunteers and church as ecumenical body. 
is said to contribute more money to poverty relief than the government (Erasmus, 2012:60), but how effective is this It has certainly been found that many churches engage in some form of poverty relief, however, these efforts are largely in the form of the charity or relief approach so critiqued by Carnegie I. In fact, one of the "lines of action' identified by Carnegie II's workgroup, was that of the church encouraging self-reliance - where communities would be empowered to help themselves. Relief work, while well meaning and legitimate in many contexts, focuses more on the symptoms than causes of poverty and implies a 'charity' approach to welfare and development rather than the community development approach advocated by the South African state (Lombard, 2009). This approach, most famously identified by David Korten (1990:115) as a 'Generation One' approach "involves the direct delivery of services to meet an immediate deficiency or shortage experienced by the beneficiary population, such as needs for food, health care or shelter". In recent years Ignatius Swart has repeatedly identified the South African church as needing to shift in its approach to social development from Korten's Generation One and Two approaches towards more sustainable interventions (Swart, 2006; Swart, 2004; Swart \& Venter, 2001).

It has been argued that the silence of the church with regards to public discourse as well as the employment of a largely charity model in addressing poverty and inequality, may have something to do with one of the key challenges mentioned by both inquiries: an inadequate theology. In the case of the churches engagement (or disengagement) with society and issues of poverty and inequality is largely shaped by theology (Swart, 2004:8; cf. Bowers-Du Toit, 2012:257). Margaret Nash noted in the second inquiry, that a spiritualisation of the gospel tended to have the "same effects as Valium ... tends to buttress rather than challenge the status quo". All too often as evidenced by the findings of both inquiries - the church has overemphasised the spiritual dimension of its calling over the social. ${ }^{30}$ In fact, the first inquiry had pointed out that should the church continue to overemphasise the spiritual dimension of its calling, it would eventually cost the church its "influence and authority with regards to the great social questions of the country." The focus of my research over the past few years has been largely on the role such theologies (good or bad) play in the churches engagement with poverty and there is significant evidence that the failure of the church to meet Carnegie II's goal of 'relating teaching and preaching to social reality'

30 This applies more specifically to evangelical circles, however, it is my impression that even those churches who may fall outside of this categorisation struggle at times to actively engage socio-economic challenges - as the case was with Nash's study which included only mainline denominations (Nash, 1984:2). It is hoped that future research will address such issues. 
has largely been because of inadequacy here (cf. Bowers-Du Toit, 2010; Bowers-Du Toit 2009). ${ }^{31}$ One of the newer 'troubling theologies' in our context has been that of the so-called "Prosperity Gospel" which has taken root in many poor communities. This theology, promises the faithful success, health and prosperity based on how much money they contribute to the congregation. Those who suffer from a lack of prosperity are regarded as 'cursed' and are simply promised that the key to financial prosperity is to give more (Huliselan, 2008:33; cf. Williams, 1987:33). Such a heretical theology is potentially further disempowering to the poor and it is also clear that in South Africa today, many ministers are benefitting from a theology that makes them rich - and famous (Theron, 2011:8). It is, nevertheless, interesting to note that church streams often associated with prosperity theology, such as Pentecostalism, who were previously accused of dualism and an over spiritualisation of the gospel are now being seen as encouraging a sense of agency in their members and are noted as "probably the best able to reach out to South Africa's marginalised communities" (Centre for Development and Enterprise, 2009:32,34). The latter brings into sharp relief the importance of disciplines such as Practical Theology engaging with this constituency, in order to better understand their contribution to our current context and discourse.

Good theology of the kind which assists in activating agency with regards to issues of poverty and inequality, is of course also shaped by adequate training, a fact mentioned by Carnegie I. Theological training that is more "pertinent and practical" was identified by Carnegie I as one of the ways in which the church could be more relevant and move away from a charity approach. This clearly has not happened to the degree required and is key if the church and FBO's are going to be able to address the scourge of poverty in a more effective and sophisticated manner in line with the key competencies required for community development work such as project management, $\mathrm{M} \& \mathrm{E}$, community and resource mobilisation etc. It is interesting to note that while several tertiary institutions were key in shaping liberation theologians at the time of Carnegie II, other institutions such as UKZN, the University of Stellenbosch and Cornerstone Institute now have training that is specifically focused

31 The congregational and denominational persuasion of these studies included both mainline church groups (NG/DRC, Anglican, Catholic as well as more evangelical and charismatic/Pentecostal groups). The Cape Flats Case study (2010) focused on ways in which understandings of soteriology and eschatology shaped the praxis of (largely) evangelical congregations in a Cape Flats community, while the second study (2012) focused on the manner in which key theological themes (such as love of neighbour, the imago dei, diakonia etc. as found in confessional documents) played a role in the manner in which mainline churches (DRC, URC, Anglican and Catholic) in the Paarl area responded to poverty. 
on preparing theological students for community development work. Faith Based Organisations such as The Warehouse (an Anglican FBO) have also recognised the need for congregations to be trained and equipped and have begun the work of training laity and church leaders and improving their consciousness with regards to justice and community development initiatives. It is important to note, nevertheless, that "pertinent and practical" theological training in development may according to Balcomb (2012:6-20) become somewhat instrumentalist in nature and far removed from the discipline of theology.

\section{CONCLUSION}

In a post-apartheid context it is clear that the church appears to struggle with what Erasmus (2012:241) terms a "double legacy."

... while on the one hand there is evidence that suggests that churches are trusted institutions, much involved in serving the poor and hence perceived positively by the population. On the other hand, similarly pervasive evidence suggests that churches inhibit change, are reluctantly involved with poor and vulnerable people, and that they supported Apartheid".

This is no more evident than in tracing the trajectory of these inquiries. In tracing the trajectory of the Carnegie discourse, one is able to observe both the ways in which in which the church redefined its relationship with the state through its engagement with poverty - as well as the tensions inherent in such engagement. Each inquiry revealed a different form of engagement with the state - one outlined the manner in which co-operation with the state secured the wellbeing of the poor white, while the others outlined the manner in which socio-economic inequality became another rallying point of resistance to the Apartheid system (which had been reinforced by the former inquiry). It is also clear that it is precisely this "double legacy" and the rich lessons which can be drawn on from this legacy, that offer the possibility of providing the South African church today with resources at a point in history where the state (in the form of the National Development Plan) is calling us to respond to the structural challenges of poverty and inequality our land faces. Our plotting of a way forward in a post-Apartheid context must, therefore, acknowledge these tensions while calling for a renewed and sustained effort - especially by the church in its congregational configuration - to confront the various social, political and theological challenges faced by a changing context for the sake of its witness. The challenge of Drs DF Malan and AA Boesak's remains. To "get up and walk" means that the church is to continue to: 
... work for the day political, social and economic change shall become

a reality, so that all of South Africa's people, including the poor, shall be able to live as human beings as God had intended for them to live (Boesak, 1984:8).

\section{BIBLIOGRAPHY}

Albertyn, JR \& Rothman, ME 1932. Die Armblankevraagstuk in Suid Afrika: Verslag van die Carnegie Kommissie - Deel V: Sosiologiese Verslag. Stellenbosch: Pro Ecclesia.

Balcomb, AO 2012. What Theology? Whose Development? - Interrogating Theology and Development in the Secular Academy. JTSA. March, 142 (2012):6-20

Boesak, A 1984. Poverty: The Moral Challenge: Get up and Walk, Paper no. 308. In Second Carnegie Inquiry into Poverty \& Development. Southern Africa Labour and Development Research Unit. Cape Town: University of Cape Town

Boff, L 1986. Ecclesiogenesis: The Base Communities Reinvent the Church. Maryknoll: Orbis.

Bosch, DJ 1991. Transforming Mission: Paradigm Shifts in Theology of Mission. Maryknoll: Orbis.

Bowers Du Toit, 2009. Theology and Praxis: Friends, Foes or Mere Acquaintances? A Case Study from Paarl. JTSA, March, 133 (2009):103-104.

--- 2012. Remembrance and Renewal: Exploring the Role of the Church as an Agent of Welfare after 15 years of Democracy. NGTT, 53 (Supp 2):205-216

Bowers Du Toit, N \& Nkomo, G 2014. The on-going challenge of restorative justice in South Africa: How and why wealthy surburban congregations are responding to poverty and inequality. HTS Theological Studies. 70(2), Art.\#2022, 8 pages. http://dx.doi.org/10.4102/hts.v70i2.2022

Burger, $\mathrm{R}$ et al 2010. The Challenge of Poverty and Social Exclusion in PostApartheid South Africa, in Swart, I et al (eds), Religion and Social Development in Post-Apartheid South Africa, 61-74, Stellenbosch: Sun Press

Burrows, S 2014. Die Rol van Prediking in die Bevordering van Gemeenskapsontwikkeling: ' $n$ kontekstueel-teologiese besinning. D Th Thesis. University of Stellenbosch: Stellenbosch 
C3 2012. About Carnegie 3. Viewed 18 August 2014, from http://www.carnegie3.org. za/about.

Cochrane, J, De Gruchy, J, Martin, S 1999. Facing the Truth: South African Faith Communities and the Truth and Reconciliation Commission. Cape Town: David Philip.

De Gruchy, J \& Villa-Vicencio, C 1983. Apartheid is a Heresy. Cape Town: David Philip.

Erasmus, J 2012. Religious Demographics in Post Apartheid South Africa, In I. Swart, A. Gouws, P. Pettersson, J. Erasmus \& F. Bosman (eds) Welfare, Religion and Gender in a Post Apartheid South Africa: Constructing a NorthSouth Dialogue. Stellenbosch: Sun Press

Erasmus, J 2008. Research Report on Part 2 of the Project: Welfare and Religion in a Global Perspective: Theoretical and Methodological Exchange Across the North-South Divides (WGRIP): Church, Welfare and Gender, the Case of Paarl. Unpublished report, Unit of Religious and Demographic Research, Faculty of Theology, Stellenbosch University.

Erasmus, J 2012. Double Legacy - Perceptions of Chruches as Welfare Agents in the New South Africa, In I Swart, A Gouws, P Pettersson, J Erasmus \& F Bosman (eds) Welfare, Religion and Gender in a Post Apartheid South Africa: Constructing a North-South Dialogue. Stellenbosch: Sun Press

Hamburg, D 1984. Address From the President of the Carnegie Corporation of New York, Paper No. 309. In Second Carnegie Inquiry into Poverty and Development in Southern Africa. Southern Africa Labour and Development Research Unit. Cape Town: University of Cape Town.

Huliselan, B 2008. The Ecumenical Movement in the $21^{\text {st }}$ Century: Bringing Unity Down to Earth. The Ecumenical Review, no. 60 (3), 213-221.

Korten, D 1990. Getting to the 21 ${ }^{\text {st }}$ Century: Voluntary Action and the Global Agenda. West Hartford: Kumarian press

Krige, S 2008. Towards a Coherent Vision for Faith Based Development, JTSA, November, no. 132 (2008), 17.

Lombard, A n.d. Social Change though Integrated Social and Economic Development. University of Pretoria: unpublished paper, http://www.up.ac.zal dspace/bitstream/2263/234/alombard paper 2006.pdf (20 February 2009). 
Macquarrie, JA 1933. The Poor White Problem: Report of Commission of Investigation. The South African Outlook, no. 63(741), 26-29.

Mac Master, L 2008. Where have all the Pastors Gone? A Case for Public Pastoral Care in A Democratic South Africa Experiencing Growth Pains, JTSA November, no. 132 (2008), 6.

Nash, M 1984a. Church, Poverty and Development in Southern Africa, Paper No. 242. In Second Carnegie Inquiry into Poverty \& Development. Southern Africa Labour and Development Research Unit. Cape Town: University of Cape Town.

--- 1984b. Called to be Liberated and to Liberate, South African Outlook, 114 (1353): 38 .

n.d. National Development Plan 2030: Our Future, Make it Work: Executive Summary. National Planning Commission, Department of the Presidency, Republic of South Africa.

Pierson, PE 1993. Missions and Community Development: A Historical Perspective. In E.J. Elliston (ed), Christian Relief and Development: Developing Workers for Effective Ministry. Dallas: Word

Ras, Volk en Nasie en Volkverhoudinge. 1975. Pretoria: NG Kerk.

Smit, D 1996. Oor die Kerk as 'n Unieke Samelewingsverband. Tydskrif vir Geesteswetenskappe, 36(2): 119-127.

Swart, I \& Venter, D 2001. NGO's and Churches: Civil Society Actors and the Premise of Fourth Generation Development in South Africa, in J.K. Coetzee, J. Graaf, F. Hendricks, \& G. Wood (Eds), Development: Theory, Policy and Practice. Cape Town: Oxford

Swart, I 2004. Networks and Partnerships for Social Justice? Critical Reflection on the Pragmatic turn in the Religious Social Development Debate in South Africa. Paper presented at fourth workshop of NRF research project: "Developing a Praxis for Mobilising Faith Based Organisations (FBOs) for Social Capital and development in the Western Cape", University of Stellenbosch, RSA.

--- 2006. The Churches and the Development Debate: the Promise of a Fourth Generation Approach. Sun Press: Stellenbosch 
--- 2010. Networks and Partnerships for Social justice? The Pragmatic turn in the religious social development debate in South Africa. In I. Swart, H. Rocjer, S. Green \& J. Erasmus (eds) Religion and Development in a Post-Apartheid South Africa: Perspectives for Critical Engagement. Stellenboach: Sun Press

--- 2012. Transforming Social Welfare? The Religious Discourse on Social Development in Post Apartheid South Africa. In I. Swart, A. Gouws, P. Pettersson, J. Erasmus \& F. Bosman(eds) Welfare, Religion and Gender in a Post Apartheid South Africa: Constructing a North-South Dialogue. Stellenbosch: Sun Press

The Poor White and Society: A Human Document. 1933. The South African Outlook, 63(746): 149-152.

Theron, J 2011. Money Matters in Pentecostal Circles. Studia Historiae Ecclesiasticae, 37(2): 153-171

Thomas, NE (Ed.) 1995. Classic Texts in Mission \& World Christianity. Maryknoll: Orbis.

--- n.a. 2008. Under the Radar: Pentecostalism in South Africa and its Potential Socio-Economic Role. Centre for Development and Enterprise: Parktown Williams, DT 1987. The Heresy of Prosperity Teaching. Journal of Theology for Southern Africa, 61(December), 33-44

Wilson, F 1984. Macro Views from Micro Coverage: Carnegie Conference Papers. South African Outlook, 114(1356): 82-87.

--- 1989. The Carnegie Report. South African Outlook, 119 (1412): 23-36.

Wilson, F \& Ramphele, M 1989. Uprooting Poverty: The South African Challenge. Cape Town: David Philip. 
